\title{
PENGARUH KARAKTER ENTREPRENEUR TERHADAP MINAT BERWIRAUSAHA (Studi Empiris Pada Santri di Pondok Pesantren Al-Ittifaq Ciwidey Bandung)
}

\author{
Miko Polindi \\ Research Center Media Group \\ E-mail: mikopolindi25@gmail.com
}

Abstract: This research is based on seeing the success of some students of Al-Ittifaq Pesantren who become entrepreneurs. The purpose of this study is to find out how much influence the entrepreneur character of entrepreneurship interests of boarding school students al-ittifaq Ciwidey Bandung. With the rationale based on the theory proposed by William D. Bygrave, Suryana, Theo Suhardi and Slameto which suggests that in general the factors that affect one's entrepreneurial interest is the factor of personality (from within oneself). So from this theory researchers used entrepreneur character variables as an independent variable and entrepreneurship interest as a dependent variable. The research method used in this research is descriptive method verifikatif, through survey with data collection techniques using questionnaire and observation. The samples taken were 10\% of the total population using the Slovin formula. The results of this study conclude that there is a positive but not significant influence between entrepreneur character variables on entrepreneur interest. Where the amount of influence that is equal to $0.39 \%$. There is a positive influence on this variable, in line with the theory proposed by Suryana which reveals that one of the factors that influence one's entrepreneur interest is personal factor (character / character).

Kayword: Enterpreneur Characters, EnterpreneurIinterest, Pesantren Al-Ittifaq

Abstrak: Penelitian ini bertolak dari melihat keberhasilan beberapa santri pondok Pesantren Al-Ittifaq yang menjadi entrepreneur. Tujuan dari penelitian ini yaitu untuk mengetahui seberapa besar pengaruh karakter entrepreneur terhadap minat berwirausaha santri pondok pesantren al-ittifaq Ciwidey Bandung. Dengan dasar pemikiran bertolak pada teori yang dikemukakan oleh William D. Bygrave, Suryana, Theo Suhardi dan Slameto yang mengemukakan bahwa secara umum faktor yang mempengaruhi minat berwirausaha seseorang adalah faktor personality. Sehingga dari teori ini peneliti menggunakan variabel karakter entrepreneur sebagai variabel independen dan minat berwirausaha sebagai variabel dependen. Metode penelitian yang digunakan dalam penelitian ini adalah metode diskriptif verifikatif, melalui survey dengan teknik pengumpulan data menggunakan kuisioner dan observasi. Sampel yang diambil adalah 10\% dari total populasi mengggunakan rumus Slovin. Hasil penelitian menyimpulkan bahwa, adanya pengaruh yang positif namun tidak signifikan antara variabel karakter entrepreneur terhadap minat berwirausaha, besaran pengaruh sebesar 0.39\%. hasil ini sejalan dengan teori yang dikemukakan oleh Suryana yang mengungkapkan bahwa salah satu faktor yang mempengaruhi minat berwirausaha seseorang adalah faktor pribadi (watak/karakter).

Kata Kunci: Karakter Entreprneur, Minat Berwirausaha, Pesantren Al-Ittifaq

\section{A. PENDAHULUAN}

Tingginya angka pengangguran di Indonesia saat ini merupakan salah satu problem yang harus dicarikan solusi jalan keluarnya. Problem ini diakibatkan karena pembangunan tidak mampu menyerap potensi ekonomi masyarakat, termasuk juga angkatan kerja sebagai kontributor bagi pertumbuhan ekonomi bangsa. Sementara angka produktif pertumbuhan penduduk Indonesia tidak berbanding lurus dengan ketersediaan lapangan kerja yang ada.
Sehingga yang terjadi adalah tingginya angka pengangguran.

Tingginya angka pengangguran tersebut merupakan dampak dari tidak sebandingnya antara jumlah para pencari kerja dengan jumlah lapangan kerja yang tersedia. Keadaan ini diakibatkan dari pola pikir yang diwujudkan oleh mereka yang masih berorientasi kepada cita-cita untuk menjadi pegawai ketika selesai dari pendidikan yang di tempuh. Jadi merupakan suatu kewajaran jika populasi 
wirausaha di Indonesia masih terbilang rendah. Hal tersebut terlihat pada tabel berikut:

\section{Tabel}

Perbandingan Populasi Wirausaha (Entrepreneur) di 5 Negara ASEAN ${ }^{1}$

\begin{tabular}{|c|l|c|}
\hline No & Negara & Populasi Wirausaha \\
\hline 1 & Singapura & $7 \%$ \\
\hline 2 & Malaysia & $5 \%$ \\
\hline 3 & Thailand & $4,5 \%$ \\
\hline 4 & Vietnam & $3,3 \%$ \\
\hline 5 & Indonesia & $1,5 \%$ \\
\hline
\end{tabular}

Sumber: SUARA.COM, oleh ketua BPP HIPMI, Mei 2016

Oleh karena itu sudah saatnya bangsa Indonesia memikirkan dan mencari strategi sebagai terobosan dengan menanamkan nilai-nilai kewirausahaan bagi banyak orang terutama dikalangan generasi muda atau kalangan terdidik, yang akan menimbulkan jiwa kreativitas untuk berbisnis atau berwirausaha sendiri dan tidak bergantung kepada pencarian kerja yang semakin hari semakin sempit dan sulit. Dengan demikian nilai-nilai kewirausahaan harus ditanamkan sedini mungkin. Salah satu upaya dalam menanamkan jiwa kewiausahaan yaitu melalui lembaga pendidikan. Penerapan nilai-nilai kewirausahaan di kalangan generasi muda dapat dilakukan melalui dunia pendidikan baik formal maupun non formal.

\footnotetext{
${ }^{1}$ Harian Suara.com, Jumlah Pengusaha Di
} Indonesia Baru 15 persen dari total penduduknya, Mei 2016.
Salah satu lembaga pendidikan yang ikut berpartisipasi dalam mewujudkan pemasyarakatan kewirausahaan saat ini adalah lembaga pendidikan pondok pesantren. Pergeseran lembaga pendidikan pondok pesantren menuju orientasi kemandirian ekonomi atau kewirusahaan, dapat dilihat dari beberapa pondok pesantren di era sekarang ini yang telah menerapakan sistem pembelajaran tentang kewirausahaan di lingkungannya. Beberapa pondok pesantren yang telah mengimplementasikan sistem pembelajaran kewirausahaan diantaranya: pondok pesantren Al-Ashriyyah Nurul Iman Bogor, pondok pesantren ini dalam kegiatan kewirausahaan mengajarkan kepada santrinya yang bergerak dalam bidang agrobisnis, produksi dan jasa. Pondok Pesantren Nusantara Depok, pondok pesantren ini prioritas utamanya disamping mengarahkan peserta didiknya (santri) menghafal Al-Qur'an juga memprioritaskan dalam bidang kemandirian wirausaha. Pesantren Entrepreneur Miftahul Falah Bogor, pesantren ini bergerak dalam bidang kewirausahaan dengan program kegiatan Wisatapreneur, Agrowisata dan Outbound. Dan yang tidak kalah menariknya unuk dijadikan objek penelitian tentang kewirausahaan dikalangan santri yaitu di pondok pesantren Al-Ittifaq Ciwidey Bandung. 


\section{B. KAJIAN TEORI}

\section{Teori Karakter Entrepreneur.}

\section{a. Definisi Karakter.}

Kata karakter berasal dari bahasa latin yaitu kharakter, kharassein, dan kharax, yang maknanya tools for marking, to engrave, dan pointed stake. Kata ini banyak digunakan kembali dalam bahasa Prancis yaitu caractere pada abad ke-14 dan kemudian masuk kedalam bahasa Inggris menjadi character, hingga akhirnya menjadi bahasa Indonesia yaitu karakter. ${ }^{2}$ Karakter mengandung pengertian yaitu suatu kualitas positif yang dimiliki seseorang, sehingga membuatnya menarik dan atraktif. Dengan kata lain karakter juga bisa diartikan sebagai reputasi seseorang atau seseorang yang memiliki kepribadian yang eksentrik. ${ }^{3}$ Karakter adalah suatu keadaan jiwa yang tampak dalam tingkah laku dan perbuatan sebagai dampak dari pengaruh pembawaan (hereditas) dan lingkungan. ${ }^{4}$ Karakter diartikan sebagai tabiat, watak: sifat-sifat

${ }^{2}$ Rifki Nur Alhaqi, Karakter Wirausaha, Penerapan Kunci Sukses Usaha dan Peranan Pemerintah terhadap Keberhasilan Usaha, Tesis, (UNPAD Bandung: Program Studi Magister Manajemen, 2016), hlm. 26

${ }^{3}$ Yuyus Suryana dan Kartib Bayu, Kewirausahaan: Pendekatan Karakteristik Wirausahawan Sukses, (Jakarta: Kencana, 2011), hlm.50

${ }^{4}$ Baharuddin, Psikologi Pendidikan Refleksi Teoritis terhadap Fenomena, (Yogyakarta: Ar-Ruzz Media, 2009), hlm. 193 kejiwaan, akhlak, atau budi pekerti yang membedakan seseorang dengan yang lainnya. Karakter lebih bersifat stabil, herediter atau bawaan, dan bersifat normatif. ${ }^{5}$ Pada prinsipnya, melihat dari pengertian tersebut diatas dapat dikatakan bahwa karakter bisa diubah dengan cara di didik. Dikatakan demikian karena menurut M. Dalyono, bahwa setiap perkembangan pribadi seseorang merupakan hasil interaksi hereditas dan lingkungan. ${ }^{6}$ Artinya disini bahwa pribadi seseorang dan perkembangannya adalah produk dari hereditas dan lingkungan. Hereditas merupakan aspek yang mempengaruhi perkembangan pribadi individu yang berasal dari dalam diri individu itu sendiri, sedangkan lingkungan adalah aspek yang mempengaruhi perkembangan pribadi individu yang beasal dari luar diri individu.

\section{b. Karakter Entrepreneur.}

Para entrepreneur adalah individuindividu yang berorientasi pada tindakan dan mempunyai motivasi yang tinggi dalam mengambil resiko untuk mencapai tujuannya. Seorang entrepreneur harus memiliki karakter

\footnotetext{
${ }^{5}$ Tri Rusmi Widayatun, Ilmu Prilaku, (Jakarta: CV. Sagung Seto, 2009), hlm. 183

${ }^{6}$ M. Dalyono, Psikologi Pendidikan, (Jakarta: Rineka Cipta, 2012), hlm. 143
} 
yang memberikan cerminan sebuah profil dari seorang entrepreneur itu sendiri. Karakter entrepreneur dapat dilihat dari berbagai aspek kepribadian, seperti jiwa, waktak, sikap dan prilaku seseorang.

Menurut Geoffrey G. Meredith, seorang entrepreneur harus memiliki karakter sebagai berikut: ${ }^{7}$

1) Percaya diri dan optimis

Karakter ini mencerminkan individu yang memiliki kepercayaan diri yang kuat, ketidaktergantungan terhadap orang lain, dan individualistik dalam artian memiliki sikap atau watak yang mandiri dan memiliki keyakinan yang tinggi bahwa ia mampu mencapai tujuan yang diinginkan.

2) Berorientasi pada tugas dan hasil Memposisikan bahwa prestasi adalah suatu kebutuhan, disiplin diri yang tinggi, energik, berpikir kritis, kerja keras, tekun dan tabah, serta inisiatif. Karena dalam berwirausaha peluang didapat apabila ada inisiatif.

3) Berani mengambil resiko dan menyukai tantangan

${ }^{7}$ Geoffrey G. Meredith, Kewirausahaan: Teori dan Praktik, di terjemahan oleh Andre Asparsayogi, (Jakarta: Pustaka Binaman Pressindo, 2002), hlm. 5.
Entrepreneur adalah orang yang lebih tertarik pada usaha-usaha yang memiliki tantangan untuk mencapai kesuksesan ataupun kegagalan sebagai dari resiko daripada usaha yang kurang menantang. Memiliki kemampuan menilai resiko secara realistis, kesediaan untuk menggunakan kemampuan dalam memcari peluang dan kemungkinan untuk memperoleh keuntungan. Dan kesediaan kemungkinan untuk rugi, sukses atau gagal yang merupakan pilihan terhadap resiko.

4) Kepemimpinan

Berjiwa kepemimpinan, mudah beradaptasi dengan orang lain atau lingkungan, dan terbuka terhadap saran dan kritik. Seorang entrepreneur harus memiliki jiwa kepemimpinan, kepeloporan, dan keteladanan. Pada prinsipnya, setiap individu memiliki jiwa kepemimpinan, akan tetapi yang membedakannya adalah dimana dan bagaimana ia dibentuk sehingga menjadi jiwa yang tangguh dan menjadi sebuah karakter.

5) Keorisinilan

Maksud dari keorisinilan disini ialah kreatif dan inovatif. Artinya seorang entrepreneur harus 
memiliki perspektif atau pandangan ke masa depan, mampu menciptakan sebuah produk yang baru yang berbeda dari yang saat ini. Dan memiliki kecakapan dalam memunculkan ide-ide baru dalam mendirikan atau menjalankan kegiatan usahanya.

6) Berorientasi ke masa depan Memiliki visi, misi dan pandangan ke masa depan. Tentunya seorang entrepreneur harus mempunyai strategi atau langkah-langkah tertentu untuk rencana kemajuan usahanya dimasa yang akan datang. Dan harus dapat menganalisa dan melihat dari berbagai sudut pandang terhadap usaha yang akan atau sedang dijalaninya, agar dapat mempunyai gammbaran prospek atau kemajuan usahanya di masa depan. Menurut Bygrave, karakter seorang entrepreneur yang berhasil memiliki sifat-sifat sebagai berikut: ${ }^{8}$

1) Dreams (impian). Seorang entrepreneur harus mempunyai impian dan visi tentang bagaimana keinginannya terhadap kemajuan usahanya dapat terwujud.

2) Deciveness (ketegasan). Seorang entrepreneur adalah orang yang

${ }^{8}$ William D. Bygrave, The Portable MBA in Entrepreneurship..., hlm. 5 mampu mengambil keputusan cepat dengan penuh perhitungan dan pertimbangan yang matang, karena ini merupakan kunci dari kesuksesan usahanya. Sehingga seorang entrepreneur adalah orang yang tidak menyukai bekerja lambat.

3) Doer (prilaku/bertindak). Begitu mengambil sebuah keputusan, langsung ditindaklanjuti, dan tidak mau menunda-nunda kesempatan yang dapat dimanfaatkan.

4) Determination (kemantapan hati untuk maju). Memiliki rasa tanggung jawab yang tinggi, dan tidak mudah menyerah dalam menghadapi masalah sesulit apapun.

5) Dedication (dedikasi). Memiliki dedikasi yang tinggi terhadap usaha yang dijalaninya, sehingga tidak jarang seorang entrepreneur kadang lebih mementingkan usahanya dibandingkan keluarganya.

6) Devotion (kesetiaan). Sangat senang dan mencintai segala hal yang terdapat dalam usaha/bisnis yang dijalaninya.

7) Details (teliti). Sangat memperhatikan faktor kritis yang terperinci dan tidak mengabaikan hal-hal kecil yang dapat 
menghabat keberlangsungan

usahanya.

8) Destiny (takdir). Bertanggung jawab terhadap tujuan yang hendak di capai, serta tidak bergantung kepada orang lain dan memiliki kebebasan.

9) Dollars. Artinya uang bukanlah motivasinya, tetapi uang dijadikan sebagai tolak ukur keberhasilan kinerjanya dalam menjalankan usahanya.

10) Distribute (pembagian). Seorang entrepreneur akan bersedia membagikan kepemilikan usahanya tehadap orang lain yang dipercaya dan mau diajak kerjasama untuk meraih kesuksesan dalam menjalankan usahanya.

Menurut Suryana, seorang entrepreneur yang ingin berhasil harus memiliki karakter sebagai berikut: ${ }^{9}$

1) Percaya diri

Percaya diri merupakan suatu perpaduan antara sikap dan kepercayaan seseorang dalam menghadapi tugas pekerjaan atau tanggung jawab. Dalam praktiknya sikap dan kepercayaan merupakan keyakinan untuk memulai, melakukan dan menyelesaikan tugas atau pekerjaan yang menjadi tanggung jawab yang dihadapi. Seorang yang memiliki percaya diri cenderung memiliki keyakinan akan kemampuan bahwa dirinya dapat mencapai keberhasilan yang diinginkan.

2) Berorientasi tugas dan hasil Seseorang yang memiliki tingkat percaya diri yang tinggi, tidak mudah menyerah terhadap kegagalan dan tidak gampang puas akan keberhasilan yang diraihnya saat ini, merupakan ciri dari seseorang yang berorientasi kepada tugas dan hasil. Seseorang yang mengutamakan tugas dan hasil akan selalu mengutamakan nilai-nilai motif berprestasi, tekun, kerja keras, tabah dan berorientasi kepada prestasi, akan mempunyai dorongan kuat untuk selalu semangat/energik dan inisiatif. "Inisiatif bearti memulai atau tindakan awal yang dambil seseorang sehingga pekerjaan dapat terlaksana". ${ }^{10}$ Inisiatif yang dimaksud disini artinya selalu

\footnotetext{
${ }^{10}$ Bambang Murdaka Eka Jati dan Tri Kuntoro Priyambodo, Kewirausahaan Technopreneurship untuk Mahasiswa Ilmu-ilmu Eksakta, (Yogyakarta: ANDI, 2015), hlm.40
} 
ingin mencari peluang dan memulainya.

3) Berani menghadapi resiko

Berani menghadapi resiko dengan perhitungan yang matang dan optimisme akan keberhasilan yang diraih juga dipengaruhi dari tingginya rasa percaya diri dimiliki. Artinya keberanian menghadapi resiko dan optimisme dipengaruhi oleh rasa percaya diri. Seseorang yang memiliki tingkat rasa percaya diri yang tinggi relatif akan mampu menghadapi dan menyelesaikan masalah yang dihadapi sendiri. Oleh karena itu, semakin besar keyakinan seseorang akan kemampuan diri sendiri, maka akan semakin besar pula keyakinananya akan kesanggupan untuk menghadapi dan mencoba hal yang menurut orang lain beresiko.

4) Berorientasi masa depan

Seseorang yang berorientasi masa depan adalah seseorang memiliki pandangan yang jauh ke depan. Ia akan selalu berupaya untuk menciptakan hal-hal baru yang direncanakan sedini mungkin dengan tujuan untuk keberhasilan dimasa yang akan datang. Sehingga apabila meraih suatu prestasi, ia tidak cepat puas akan keberhasilan atas prestasi yang diraihnya. Seseorang yang berorientasi ke masa depan akan selalu merencanakan dan menjalankan apa yang menjadi tujuannya saat ini untuk meraih keberhasilan dimasa yang akan datang.

5) Kepemimpinan

Seorang entrepreneur yang berhasil selalu memimiliki jiwa kepemimpinan atau leadership. Ia akan selalu berusaha untuk memberikan seseuatu yang berbeda dari yang lain, memiliki jiwa kepeloporan dan keteladanan dengan kemampuan kreatif dan inovatifnya. Ia akan selalu memanfaatkan perbedaan dari produk baik barang ataupun jasa yang dihasilkannya sebagai sesuatu penambah nilai untuk menjadi unggul dari yang lain. Sehingga seorang entrepreneur yang memiliki karakter kepemimpinan akan memiliki sifat kepeloporan, keteladanan dan mampu berfikir menciptakan suatu perbedaan yang memiliki nilai dari orang lain.

6) Keorisinalitasan (kreatif dan inovatif)

Kreatif adalah kemampuan berfikir seseorang untuk menciptakan 
suatu hal baru yang berbeda dari yang lainnya, sedangkan inovatif adalah kemampuan seseorang dalam bertindak menghasilkan sesuatu yang baru dan berbeda dari yang lain. Seorang entrepreneur yang kreatifitasnya tinggi maka ia akan mampu menciptkan inovasiinovasi baru dalam upaya merebut kesempatan atau peluang dari yang lainnya.

Menurut Yuyus Suryana ciri-ciri karakter yang dimiliki oleh seorang entrepreneur secara garis besar yaitu: ${ }^{11}$

1) Memiliki motivasi untuk berprestasi yang tinggi, karakteristik ini terdiri atas: Pekerja keras (hard worker); Tidak pernah menyerah (never surrender); Memiliki semangat (spirit) dan memiliki komitmen (comitted) yang tinggi.

2) Berorientasi kemasa depan, karakteristik ini terdiri atas: Visioner; Befikir positif (positive thinking) dan memiliki pengetahuan (knowledge) yang Luas.

3) Memiliki jiwa kepemimpinan yang unggul, karakteristik ini terdiri atas: Keberanian untuk bertindak

${ }^{11}$ Yuyus Suryana dan Kartib Bayu, Kewirausahaan..., hlm. 66 (dare to act); Membangun Tim yang Baik (good team leader); Berpikir dan berjiwa besar; Berani mengambil resiko; Having mentor; Pikiran yang terbuka (open minded) dan Kepercayaan (trusted).

4) Memiliki jaringan usaha yang luas, karakteristik ini terdiri atas: Jaringan kerja (net working), Teman (friends) dan Kerja sama (coorperative).

5) Tanggap dan kreatif dalam menghadapi perubahan, karakteristik ini terdiri atas: Berpikir kritis (critie); Menyenangkan; Proaktif; Kreatif; Inovatif; Efesien; Produktif dan Orsinal.

Menurut Mudjiarto karakteristik utama yang terdapat dalam diri seorang entrepreneur adalah sebagai berikut: ${ }^{12}$

1) Dorongan berprestasi

Dalam jiwa seorang entrepreneur terdapat dorongan atau rangsangan yang kuat dan mempunyai keinginan besar untuk mencapai prestasi, yang dirangsang oleh kebutuhan untuk melampaui hasilhasil yang diraih mereka pada

${ }^{12}$ Mujiarto dan Aliaras Wahid, Membangun Karakter dan Kepribadian Kewirausahaan, (Yogyakarta: Graha Ilmu, 2006), hlm. 3 
masa lampau. Sehingga mereka termotivasi untuk bertindak secara individual untuk melaksanakan pencapaian tujuan yang menantang.

2) Bekerja keras

Sebagian besar terkadang seorang entrepreneur "gila kerja" dengan tujuan untuk mencapai apa yang dicita-citakan. Akan tatapi keadaan ini merupakan wujud dari kerja keras, karena dengan kerja keras maka keberhasilan atau prestasi akan dicapai.

3) Memperhatikan kualitas

Seorang entrepreneur menangani dan mengawasi usaha/bisnisnya sendiri sampai mandiri, sebelum ia memulai usaha yang baru. Dalam menjalankan usaha/bisnisnya, ia harus memperhatiakn kualitas baik manajemen ataupun produknya untuk progress usaha/bisnisnya dimasa yang akan datang.

4) Bertanggung jawab

Artinya seorang entrepreneur harus mampu bertanggung jawab atas usaha/bisnisnya baik secara moral maupun legal.

5) Berorientasi pada imbalan

Seorang entrepreneur akan mengharapkan imblan yang sepadan atas usaha/bisnis yang dijalankannya. Imbalan bukan hanya sekedar uang, namun juga pengakuan dan penghormatan. Akan tetapi uang bukanlah prioritas utama, melaikan menjadi tolak ukur dalam pencapaian keberhasilan usahanya. Sehingga disini uang semakin kurang berarti menjadi motivator utama, melainkan uang lebih dijadikan sebagai alat ukur hingga dimana pencapaian prestasi mereka.

6) Optimis

Artinya seorang entrpreneur harus memiliki keyakinan akan kemampuan meraih keberhasilan. Ia harus yakin bahwa usaha yang dilakukannya saat ini akan mengantakannya kepada kesuksesan di masa depan.

7) Berorientasi kepada hasil karya yang baik (excellencen oriented)

Meraih kesuksesan adalah tujuan dari seorang entrepreneur. Dengan demikian, dalam upaya meraih kesuksesan ia akan menciptakan ide-ide kreatifitasnya yang baik. Dalam memunculkan sebuah inovasi yang baru, ia akan memprioritaskan pada hasil yang berkualitas.

Menurut Totok S. Wiryasaputra bahwa karakter entrepreneur terdiri 
dari sepuluh sikap dasar (karakter) yaitu: ${ }^{13}$

1) Visioner (visioner). Artinya seorang entrepreneur harus mampu melihat jauh kedepan, selalu berusaha melakukan yang terbaik pada massa kini dan merencanakan masa depan yang lebih baik lagi.

2) Positive (bersikap positif). Artinya selalu berpikir positif dan tidak tergoda untuk memikirkan hal-hal negatif. Sehingga dengan bersikap positif, seorang entrepreneur akan mampu mengubah tantangan menjadi peluang dan selalu berpikir akan sesuatu yang lebih besar dalam meraih sukses.

3) Confident (percaya diri). Sikap percaya diri akan membimbing seorang entrepreneur dalam setiap mengambil keputusan dan langkahnya. Dengan memiliki sikap percaya diri akan memberikan sikap ketegasan pada seorang entrepreneur dalam mengambil keputusan atau menentukan pilihan.

4) Genuine (asli). Artinya mempunyai ide, pemimikiran atau pendapat dan mungkin model

${ }^{13}$ Lihat, Totok S. Wiryasaputra, Entrepreneur: Anda Merdeka jadi Bos, (Jakarta: Tridharma Manunggal, 2004), hlm. 3-4 sendiri. Seorang entrepreneur harus mampu menciptakan sesuatu yang baru sebagai modal dalam bersaing dari hasil kreatifitas sendiri. Baru yang dimaksud disini bukan berarti sesuatu yang betulbetul baru, akan tetapi bisa saja yang dijual adalah produk saat ini yang sama dengan yang lain tetapi ada nilai tambah atau baru yang memberikan perbedaan dari produk sebelumnya atau dari yang lain.

5) Goal Oriented (berpusat pada tujuan). Selalu berorientasi pada tugas dan hasil. Artinya seorang entrepreneur ingin selalu berprestasi, berorientasi pada laba, tekun, tabah, kerja keras, dan disiplin dalam mencapai sesuatu yang telah ditetapkan. Dengan kata lain seorang entrepreneur harus fokus pada tujuan yang telah direncanakan agar dapat meraih suskses yang diinginkan.

6) Persistent (tahan uji). Artinya seorang entrepreneur memiliki keinginan untuk terus maju, "mempunyai tenaga" dan semangat yang tinggi, pantang menyerah dan tidak mudah putus asa.

7) Ready to face a risk (siap menghadapi resiko). Artinya 
seorang entrepreneur harus siap sedia menghadapi resiko yang kemungkinan terjadi dihadapannya, baik resiko kegagalan, persaingan dari kompetitor lainnya, maupun untung rugi, semua itu harus dihadapi dengan penuh keyakinan. Oleh karena itu seorang entrepreneur harus membuat perkiraan dan perencanaan yang matang, dalam upaya meminimalisir resiko sebagai tantangan dalam usahanya.

8) Creative (kreatif memanfaatkan peluang). Seorang entrepreneur harus mampu memanfaatkan setiap peluang yang ada. Dan bahkan bukan hanya dituntut mampu memanfaatkan peluang yang ada, tetapi juga mampu menciptakan peluang.

9) Healty Competitor (menjadi pesaing yang baik). Dunia usaha/bisnis adalah dunia yang tak bisa terlepas dari persaingan. Untuk terus dapat bertahan dan unggul dalam persaingan dalam dunia usaha/bisnis harus dihadapi dengan sikap positif. Karena dengan bersikap positif akan membuat seorang entrepreneur menjadi pesaing yang baik.
10) Democratic leader (pemimpin yang demokratis). Seorang entrepreneur harus memiliki jiwa kepemimpinan yang demokratis, mampu menjadi teladan dan inspirator bagi yang lain atau karyawan.

Dan menurut Mc Clelland bahwa dalam aspek kepribadian atau karakter entrepreneur, terdapat konsep Need for Achievement (N-Ach). Konsep ini diartikan sebagai "virus kepribadian"yang menyebabkan seseorang ingin berbuat lebih baik dan terus maju, selalu berpikir untuk berbuat yang lebih baik, dan memiliki tujuan yang realistis dengan mengambil tindakan beresiko yang benar-benar telah diperitungkan. Teori ini menyatakan bahwa ukuran $N$-Ach mampu menunjukan seberapa besar jiwa entrepreneur seseorang. Semakin tinggi nilai $N$-Ach seseorang, maka akan semakin besar pula bakat potensialnya untuk menjadi entrepreneur yang sukses. Adapun karakteristik mereka yang memiliki $N$ Ach yang tinggi yaitu sebagai berikut: ${ }^{14}$

1) Lebih menyukai pekerjaan dengan resiko yang realistis. 
2) Bekerja lebih giat dalam tugastugas yang memerlukan kemampuan mental.

3) Bekerja dengan giat bukan sematamata hanya untuk mengiginkan imbalan uang.

4) Ingin bekerja pada situasi di mana dapat diperoleh pencapaian pribadi (personal achievement).

5) Menunjukan kinerja yang lebih baik dalam kondisi yang memebrikan umpan balik yang jelas positif.

Cenderung bepikir ke masa depan serta memiliki perspektif atau pemikiran jangka panjang.

\section{c. Pengukuran Karakter Entrepreneur.}

Indikator-indikator yang dijadikan sebagai alat pengukuran karakter entrepreneur pada penelitian ini adalah sebagai berikut: Percaya diri; Kemandirian; Disiplin; Optimis; Beorientasi ke masa depan; Beorientasi pada tugas dan hasil; Berjiwa kepemimpinan/leadership; Terbuka terhadap kritik dan saran; Keberanian mengambil resiko; dan Keorisinilan (Inovatif, Kreatif dan Fleksibel).

\section{Teori Minat Berwirausaha.}

\section{a. Definisi Minat.}

Minat adalah kesadaran seseorang terhadap suatu objek, orang, masalah atau situasi yang mempunyai kaitan dengan dirinya. Menurut Khairani, minat merupakan aspek psikologis seseorang untuk menaruh perhatian yang tinggi terhadap suatu kegiatan tertentu dan mendorong yang bersangkutan untuk mealukan kegiatan tersebut. ${ }^{15}$

Dalam literatur lain juga dijelaskan bahwa minat adalah kecenderungan yang agak menetap dalam subjek untuk melakukan apa yang disenanginya atau sumber motivasi yang mendorong seseorang untuk melakukan apa yang ingin dilakukannya. ${ }^{16}$ Pendapat ini sejalan dengan pendapat yang dikemukakan oleh Winkel, yang menyatakan bahwa minat adalah kecenderungan yang menetap pada seseorang untuk merasa tertarik pada suatu bidang tertentu dan merasa senang dalam berbagai kegiatan yang berkaitan dengan bidang itu sendiri. ${ }^{17}$ Menurut Slameto, minat adalah rasa keterterikan dan rasa lebih suka pada suatu hal atau aktivitas tertentu tanpa ada yang harus menyuruh. ${ }^{18}$ Sujanto menjelaskan bahwa minat merupakan suatu pemusatan perhatian secara tidak sengaja terlahir dengan penuh

\footnotetext{
${ }^{15}$ Makmum Khairani, Psikologi Belajar, (Yogyakarta: Aswaja Pressindo, 2014), hlm.136

${ }^{16}$ Hurlock, Perkembangan Anak, (Jakarta: Erlangga, 1991), hlm. 6

${ }^{17}$ Winkel, Psikologi Pengajaran, (Yogyakarta: Media Abadi, 2004), hlm.650

${ }^{18}$ Slameto, Belajar dan Faktor-faktor yang Mempengaruhinya..., hlm.180
} 
kemauannya dan tergantung dari bakat dan lingkungannya. ${ }^{19}$

Dari beberapa definisi di atas dapat dipahami bahwa minat adalah kecenderungan yang agak menetap dalam diri subjek/individu akan ketertarikan suatu hal atau aktivitas tertentu yang mendorongnya untuk melakukan aktivitas tersebut. Minat timbul dalam diri subjek tanpa ada yang menyuruh, terlahir dengan penuh kemauannya dan tergantung dari bakat dan lingkungannya.

\section{b. Definisi Berwirausaha.}

Berwirausaha merupakan kata yang lazim digunakan di Indonesia. Dalam bahasa Inggris, kata berwirausaha disebut dengan entrepreneurship. Menurut Yadi Janwari, (Entrepreneurship are spirit, attitude, behavior, and ability to handle effort or activities that lead to the search for, create, and implement ways of working, new technologies and products to improve efficiency in order to provide better service and earn greater profits). ${ }^{20}$ Berwirausaha adalah semangat, sikap, perilaku, dan kemampuan untuk menangani usaha atau kegiatan yang mengarah pada pencarian, membuat, dan melaksanakan cara kerja, teknologi baru dan produk untuk meningkatkan efisiensi dalam rangka memberikan pelayanan yang lebih baik dan mendapatkan keuntungan yang lebih besar.

Berwirausaha merupakan proses menciptakan sesuatu yang berbeda dengan cara mengabdikan hampir sebagian dari seluruh waktu, tenaga dan pikirannya disertai dengan menanggung segala macam bentuk resiko. $^{21}$ Menurut Meredith, Berwirausaha adalah suatu pekerjaan atau karier yang harus bersifat fleksibel dan imajinatif, mampu merencanakan, mengabil resiko, menentukan keputusan-keputusan dan tindakan-tindakan untuk mencapai tujuan. ${ }^{22}$ Pendapat ini sejalan dengan yang dikemukakan oleh Suryana, yang menyatakan bahwa berwirausaha adalah kemampuan kreatif dan inovatif yang dijadikan dasar, kiat, dan sumber daya untuk mencari peluang menuju sukses. ${ }^{23}$

\section{c. Minat Berwirausaha}

Minat berwirausaha adalah kemampuan untuk memberanikan diri
${ }^{19}$ Agus Sujanto, Psikologi Sosial, (Jakarta: Rineka Cipta, 2004), hlm. 92

${ }^{20}$ Yadi Janwari, Entrepreneurship of Traditionalist Muslim in Tasikmalaya, Indonesia..., hlm.32

\footnotetext{
${ }^{21}$ Buchari Alma, Kewirausahaan: untuk Mahasiswa dan Umum..., hlm. 23

${ }^{22}$ Geoffrey G Meredith, hlm.27

${ }^{23}$ Suryana, Kewirausahaan: Pedoman Praktis: Kiat dan Proses Menuju Sukses, hlm. 2
} 
dalam memenuhi kebutuhan hidup serta memecahkan masalah hidup, memajukan usaha atau menciptakan usaha baru dengan kekuatan yang ada pada diri sendiri. ${ }^{24}$ Taormina and Sammi, mengemukakan bahwa minat berwirausaha adalah kecenderungan hati dalam diri subjek untuk tertarik menciptkan suatu usah baru yang kemudian mengorganisir, mengatur, menanggung resiko dan mengembangkan usaha yang diciptkannya tersebut. $^{25}$ Menurut Maman Suryaman, minat berwirausaha adalah gejala psikis untuk memusatkan perhatian dan berbuat sesuatu terhadap wirausaha itu dengan perasaan senang karena membawa manfaat bagi dirinya. ${ }^{26}$ Nielmasari, dalam penelitiannya mengemukakan bahwa minat berwirausaha adalah keinginan, ketertarikan serta kesediaan untuk bekerja keras atau berkemauan keras dengan adanya pemusatan perhatian untuk berusaha memenuhi kebutuhan

${ }^{24} \mathrm{TJ}$ Calo Decker and $\mathrm{CH}$ Weer, Affiliation Motivation and Interest in Entrepreneurial Careers Journal of Managerial Psychology 27 (2011): hlm.302320

${ }^{25}$ Robert J. Taormina and Sammi Kin-Mei Lao, "Measuring Chinese Entrepreneurial Motivation (Personality and Environmental Influences)", International Journal of Entrepreneurial Behavior \& Research, Vol.13, No.4, (2007), hlm.200-221

${ }^{26}$ Maman Suryaman, Minat Wirausaha pada Mahasiswa Pendidikan Teknik Elektro Fakultas Teknik Universitas Negeri Semarang..., hlm.22 hidupnya tanpa merasa takut akan resiko yang dihadapi, senantiasa belajar dari kegagalan serta selalu berupaya mengembangkan usaha diciptakannya. ${ }^{27}$ Pendapat ini sejalan dengan apa yang dikemukakan oleh Ajah Supardi, yang menyatakan bahwa yang dimaksud dengan minat berwirausaha adalah keinginan, ketertarikan serta kesediaan untuk bekerja keras atau atau berkemauan keras dengan adanya pemusatan perhatian untuk berusaha memenuhi kebutuhan hidupnya tanpa merasa takut akan resiko yang akan dihadapi, senantiasa belajar dari kegagalan yang dialami, serta mengembangkan usaha yang diciptakannya. ${ }^{28}$ Menurut Feriana Budihati, minat berwirausaha adalah keinginan atau niat yang ada pada diri seseorang untuk melakukan suatu kegiatan wirausaha dengan bekerja keras dan tekun untuk mencapai kemajuan usaha, kesedian untuk menanggung macam-macam resiko yang berkaitan dengan tindakan berusaha yang dilakukannya. ${ }^{29}$ Arif Mustofa, dalam

\footnotetext{
${ }^{27}$ Nielmasari, Pengaruh Motivasi dan Nilai Pribadi terhadap Minat Berwirausaha Mahasiswa Magister Manajemen Fakultas Ekonomi dan Bisnis, Tesis, (Universitas Padjadjaran, 2014), hlm. 40.

${ }^{28}$ Ajah Supardi, Motivasi Wirausaha dan Faktor Lingkungan Terhadap Minat Wirausaha, Tesis, (Universitas Padjadjaran, 2015), hlm. 26

${ }^{29}$ Feriana Budihati, Pengaruh Pendidikan Kewirausahaan terhadap Jiwa Kewirausahaan dan
} 
penelitiannya menyatakan bahwa minat berwirausaha merupakan pemusatan perhatian pada wirausaha karena adanya rasa suka disertai keinginan mempelajari, mengetahui dan membuktikan lebih lanjut terhadap wirausaha. ${ }^{30}$ Nurul Amalia, dalam penelitiannya mengemukakan bahwa minat berwirausaha adalah kecenderungan seseorang yang mempunyai rasa tertarik dan perhatian terhadap pekerjaan yang mampu merencanakan, mengambil resiko, keputusan dan tindakan untuk mecapai tujuan dilakukan secara kreatif dan inovatif. ${ }^{31}$

\section{METODE PENELITIAN}

Metode penelitian yang digunakan dalam penelitian ini adalah metode diskriptif verifikatif. Metode penelitian diskriptif verifikatif adalah metode penelitian yang dimaksudkan untuk menyelidiki keadaan, kondisi, atau peristiwa yang hasilnya dipaparkan ke dalam bentuk penelitian, yang tujuannya untuk menganalisis kebenaran hasil

Kompetensi Kewirausahan serta dampaknya pada Minat Berwirausaha Siswa SMK Negeri 2 Purwakarta, Tesis (Universitas Padjadjaran, 2012), hlm. 48.

${ }^{30}$ Muchammad Arif Mustofa, Pengaruh Pengetahuan Kewirausahaan, Self Efficacy dan Karakter Wirausaha terhadap Minat Berwirausaha pada Siswa Kelas XI SMK N 1Depok Kabupaten Sleman, Skripsi, (Universitas Negeri Yogyakarta, 2014), hlm.22.

${ }^{31}$ Helga Nurul Amalia, Pengaruh Prestasi dan Lingkungan terhadap Minat Berwirausaha Siswa Jurusan Pemasaran SMK Diponegoro Salatiga, Skripsi, (Universitas Negeri Semarang, 2015), hlm.13. penelitian sebelumnya. ${ }^{32}$ Dan jika dilihat dari tujuannya, penelitian ini termasuk ke dalam penelitian eksplanatoris (explanatory research). Dikatakan demikian, karena penelitian ini menghubungkan 3 (tiga) variabel, yaitu Karakter Entrepreneur sebagai variabel bebas (independent variable, dengan notasi statistik $\mathrm{X}_{1}$ ) dan Lingkungan Pendidikan sebagai variabel bebas (independent variables, dengan notasi statistik X2), sedangkan Minat Berwirausaha sebagai variabel terikat (dependent variable, dengan notasi statistik Y). Penelitian ini dilakukan di Pondok Pesantren Al-Ittifaq Desa Alam Endah Kecamatan Ranca Bali Ciwidey Kabupaten Bandung.

Analisis data dilakukan dengan cara data hasil penyebaran angket ini diberi skor dan dianalisis dengan menggunakan uji statistik. Teknik analisis data yang digunakan dalam penelitian adalah teknik korelasi dan regresi, yaitu dengan korelasi sederhana untuk menentukan hubungan masing-masing variabel $\mathrm{X}$ dengan $\mathrm{Y}$, regresi sederhana, untuk menentukan kontribusi variabel $\mathrm{X}$ terhadap variabel $\mathrm{Y}$.

\section{HASIL DAN PEMBAHASAN}

Dalam menganalisis apakah ada pengaruh karakter entrepreneur terhadap minat berwirausaha, maka akan dihitung nilai koefisien determinasi parsial dan uji

\footnotetext{
${ }^{32}$ Suaharsimi Arikunto, Prosedur Penelitian:
} Suatu Pendekatan Praktik, (Jakarta: Rineka, 2001), hlm.3. 
hipotesisis variabel karakter entrepreneur.

Dengan menggunakan software SPSS 16.0

diperoleh data output Coefficient sebagai berikut:

\section{Tabel}

Coefficients $^{a}$

\begin{tabular}{|c|c|c|c|c|}
\hline & $\begin{array}{l}\text { Standardized } \\
\text { Coefficients }\end{array}$ & & & $\begin{array}{c}\text { Correlati } \\
\text { ons }\end{array}$ \\
\hline Model & Beta & $\mathrm{t}$ & Sig. & $\begin{array}{l}\text { Zero- } \\
\text { order }\end{array}$ \\
\hline 1 |l $\begin{array}{l}\text { Karakter } \\
\text { Entrepreneur }\end{array}$ & .057 & .481 & .632 & .068 \\
\hline
\end{tabular}

a. Dependent Variable: Minat

Berwirausaha

Sumber : Data primer diolah SPSS 16.0

Berdasarkan tabel diatas, nilai

koefesien untuk variabel karakter entrepreneur sebesar 0.057 dan korelasi zero-order sebesar 0.068 , sehingga diperoleh nilai Koefisien Determinasi

Parsial (KDP) sebagai berikut:

KDP variabel $\mathrm{X} 1$ terhadap $\mathrm{Y}=0.057 \mathrm{x}$

$0.068 \times 100 \%=0.39 \%$.

Untuk melihat apakah pengaruh parsial tersebut signifikan atau tidak terhadap minat berwirausaha santri di pondok Al-Ittifaq Ciwidey Bandung, dilakukan uji hipotesis parsial sebagai berikut:

$\mathrm{H}_{0} \quad$ : Tidak terdapat pengaruh yang positif dan signifikan dari karakter entrepreneur terhadap minat berwirausaha santri pondok pesantren al-ittifaq Ciwidey Bandung.

$\mathrm{H}_{1}$ : Terdapat pengaruh yang positif dan signifikan dari karakter entrepreneur terhadap minat berwirausaha santri pondok pesantren al-ittifaq Ciwidey

Bandung.

$u: 0.05$

Dasar pengambilan keputusan:

1. $\mathrm{H}_{0}$ diterima dan $\mathrm{H}_{1}$ ditolak jika $\mathrm{t}_{\text {hitung }}<$ $t_{\text {tabel, }}$ atau nilai signifikansi $\mathrm{t}>0.05$

2. $\mathrm{H}_{1}$ diterima dan $\mathrm{H}_{0}$ ditolak jika $\mathrm{t}_{\text {hitung }}>$ $\mathrm{t}_{\text {tabel, }}$ atau nilai signifikansi $\mathrm{t}<0.05$

Dalam uji statistik yang digunakan, sebagaimana pada tabel diatas terdapat bahwa nilai $\mathrm{t}$ sebesar 0.481 dan nilai propability sebesar 0.632. Dari tabel distribusi t, dengan $u$ : 0.05 dan derajat bebas $n-k-1=97$, diperoleh nilai $t_{\text {tabel }}$ sebesar 1.660. Dari nilai-nilai tersebut terlihat bahwa $t_{\text {hitung }}$ lebih kecil daripada $\mathrm{t}_{\text {tabel }}(0.481<1.660)$ dan nilai probability $>$ 0.05 itu artinya $\mathrm{H}_{0}$ diterima dan $\mathrm{H}_{1}$ ditolak. Sehingga dapat ditarik kesimpulan bahwa tidak terdapat pengaruh yang signifikan dari karakter entrepreneur terhadap minat berwirausaha santri pondok pesantren alittifaq Ciwidey Bandung.

Dari hasil tersebut, maka dapat dinyatakan bahwa karakter entrepreneur memberikan pengaruh positif tetapi tidak signifikan terhadap minat berwirausaha santri pondok pesantren al-ittifaq Ciwidey Bandung. Dalam pengujian hipotesis pada variabel karakter entrepreneur, $\mathrm{H}_{0}$ diterima artinya menunjukan tidak adanya pengaruh yang signifikan. Akan tetapi karakter entreprenuer secara parsial memberikan pengaruh yang positif terhadap minat 
berwirausaha, dengan pengaruh yang hanya sebesar $0.39 \%$.

Karakter entrepreneur merupakan ciri-ciri atau sifat kecakapan bisnis yang tampak pada diri seseorang dalam melakukan kegiatan kewirausahaan (entrepreneurship). Sikap kecakapan bisnis yang dimiliki oleh seseorang bisa muncul dari pengalaman yang ditemui dan kadang memang ada yang muncul sejak lahir atau yang disebut dengan karakter pembawaan (heriditas) dalam aspek jiwa entrepreneur.

Sehingga secara kesimpulan, pada penelitian ini memberikan penjelasan bahwa karakter entrepreneur memberikan pengaruh yang positif terhadap minat berwirausaha tetapi pengaruhnya tidak sampai kepada tarap signifikan.

Adanya pengaruh yang positif dari karakter entrepreneur terhadap minat berwirausaha pada penelitian ini, mendukung teori yang dikemukakan oleh Bygrave yang menyatakan bahwa salah satu faktor yang berperan dalam mendorong sesorang menjadi entrepreneur yaitu faktor personal (aspek-aspek pribadi seseorang). ${ }^{33}$ Teori yang dikemukakan oleh Suryana yang menyebutkan faktor yang mempengaruhi keinginan seseorang untuk menjadi seorang entrepreneur salah satunya yaitu faktor pribadi, faktor pribadi yang dimaksud yaitu aspek kepribadian seperti jiwa,

${ }^{33}$ Wiliam D. Bygrave, D. Bygrave, The Portable MBA in Entrepreneurship..., hlm. 3. watak/karakter, sikap dan prilaku. ${ }^{34}$ Dan teori yang dikemukan oleh Theo Suhardi yang mengemukakan bahwa salah satu faktor yang dapat mendorong minat seseorang untuk menjadi entreprneur yaitu faktor yang muncul dari dalam diri sendiri. ${ }^{35}$ Faktor ini lebih kepada aspek personal atau pribadi, dimana karakter entrepreneur merupakan aspek personal yang dicerminkan dari sikap, prilaku atau waktak seseorang dalam bidang kewirausahaan. Akan tetapi, ketika toeri ini diujikan pada tantanan empiris melalui penelitian ilmiah diperoleh hasil yang positif tetapi tidak sampai kepada taraf signifikan. Sehingga menurut peneliti, bahwa variabel karakter entrepreneur bukan merupakan variabel yang paling dominan yang menjadi faktor dalam mempengaruhi minat bewirausaha seseorang.

\section{E. KESIMPULAN}

Berdasarkan dari hasil penelitian melalui perhitungan dan analisis data atas, dapat disimpulkan bahwa secara parsial terdapat pengaruh positif namun tidak signifikan, antara variabel karakter entrepreneur terhadap minat berwirausaha santri pondok pesantren al-ittifaq Ciwidey Bandung. Karena dari hasil uji statistik menunjukan bahwa persentase besaran

\footnotetext{
${ }^{34}$ Suryana, Kewirausahaan: Pedoman Praktis, ,., hlm.62.

${ }^{35}$ Theo Suhardi, Entrepreneurship: Menumbuhkembangkan,,,. hlm.24.
} 
angka pengaruh masuk dalam kategori sangat rendah.

\section{DAFTAR PUSTAKA}

Abdul Kodir, Asep Koko. Dkk, Pendidikan Karakter: Membangun Generasi Berakhlak dan Berprestasi. Yogyakarta: EDITIE PUSTAKA, 2016.

Alma, Buchari. Kewirausahaan: untuk Mahasiswa dan Umum. Bandung: Alfa Beta, 2010.

Aprilianty, Eka. Pengaruh Potensi Kepribadian Wirausaha, Pengetahuan Kewirausahaan, dan Lingkungan Keluarga terhadap Minat Berwirausaha Siswa SMK Rumpun Pertanian di Daerah Istimewa Yogyakarta. Tesis. UNY: Program Studi Ekonomi, 2012.

Arikunto, Suaharsimi. Prosedur Penelitian: Suatu Pendekatan Praktik. Jakarta: Rineka, 2001.

Arif Mustofa, Muchammad. Pengaruh Pengetahuan Kewirausahaan, Self Efficacy dan Karakter Wirausaha terhadap Minat Berwirausaha pada Siswa Kelas XI SMK N lDepok Kabupaten Sleman. Skripsi. Universitas Negeri Yogyakarta, 2014.

Budihati, Feriana. Pengaruh Pendidikan Kewirausahaan terhadap Jiwa Kewirausahaan dan Kompetensi Kewirausahan serta dampaknya pada Minat Berwirausaha Siswa SMK Negeri 2 Purwakarta. Tesis. Universitas Padjadjaran, 2012.

Bugin, Burhan. Metodelogi Penenlitian Sosial \& Ekonomi. Jakarta: Kencana, 2013.

Bygrave, William D. The Portable MBA in Entrepreneurship. John Willey \& Sons, Inc. New York, 1994.

Darmaningtyas. Pendidikan Pada dan Setelah Krisis: Evaluasi Pendidikan di Masa
Krisis. Yogyakarta: Pustaka Pelajar, 1999.

Decker, TJ. Calo and Weer, CH. Affiliation Motivation and Interest In Entrepreneurial Careers, Journal of Managerial Psychology 27 (3), 302320.

Ghozali, Imam. Aplikasi Multivariate dengan Program SPSS. Semarang: Badan Penerbit Universitas Dipenogoro, 2007.

Gravetter, Frederick J., and Forzano, Lori-Ann B. Research Methods for the Behavioral Sciences. Wadsworth Publishing Company, 1985.

Hadi, Syamsul. Metode Penelitian Kuantitatif untuk Akuntansi dan Keuangan. Yogyakarta: 2006.

Hafidhuddin, Didin. Dakwah Aktual. Jakarta: Gema Insani, 1998.

Hurlock. Perkembangan Anak. Jakarta: Erlangga, 1991.

Ilham, Moh. "Pengaruh Lingkungan Keluarga, Pendidikan, dan Sosial terhadap Jiwa dan Minat Kewirusahaan Mahasiswa”. Tesis. Bogor: Repository IPB, 2012.

Istiana, Nurul. Lingkungan Keluarga, Sekolah dan Kreatifitas Anak pada Sekolah Dasar Konvensional dan Progresif di Kota Depok. Tesis.Institut Pertanian Bogor: Sekolah Pasca Sarjana, 2013.

Janwari, Yadi. Entrepreneurship of Traditionalist Muslim in Tasikmalaya, Indonesia. Saarbrucken: Scholars' Press, 2015.

Kasmir. KEWIRAUSAHAAN. Jakarta: PT.Raja Grafindo Persada, 2008.

Kasan, Thalib. Dasar-Dasar Kependidikan. Jakarta: Studia Pers, 2005.Khairani, Makmum. Psikologi Belajar. Yogyakarta: Aswaja Pressindo, 2014.

Mastuhu. Dinamika Sistem Pendidikan Pesantren. Jakarta: INIS, 1994. 
M. Dalyono. Psikologi Pendidikan. Jakarta: Rineka Cipta, 2012.

Meredith, Geoffrey G. Kewirausahaan: Teori dan Praktik. terjemahan oleh Andre Asparsayogi. Jakarta: Pustaka Binaman Pressindo, 2002.

Muhibbin Syah. Psikologi Pendidikan. Bandung: Remaja Rosdakarya, 2013.

Mujiarto dan Wahid, Aliaras. Membangun Karakter dan Kepribadian Kewirausahaan. Yogyakarta: Graha Ilmu, 2006.

Murdaka Eka Jati, Bambang dan Priyambodo, Tri Kuntoro. Kewirausahaan Technopreneurship untuk Mahasiswa Ilmu-ilmu Eksakta. Yogyakarta: ANDI, 2015.

Naim, Ngainun dan Sauqi, Achmad. Pendidikan Multikultural: Konsep dan Aplikasi. Jogjakarta: Ar-Ruzz Media, 2011.

Nielmasari. Pengaruh Motivasi dan Nilai Pribadi terhadap Minat Berwirausaha Mahasiswa Magister Manajemen Fakultas Ekonomi dan Bisnis Universitas Padjadjaran. Tesis. UNPAD Bandung: Program Studi Manajemen, Fakultas Ekonomi dan Bisnis, 2014.

Nurul Amalia, Helga. Pengaruh Prestasi dan Lingkungan terhadap Minat Berwirausaha Siswa Jurusan Pemasaran SMK Diponegoro Salatiga. Skripsi. Universitas Negeri Semarang, 2015.

Nur Alhaqi, Rifky. Karakter Wirausaha, Penerapan Kunci Sukses Usaha dan Peran Pemerintah terhadap Keberhasilan Usaha. Tesis. UNPAD Bandung: Program Magister Manajemen, Fakultas Ekonomi dan Bisnis, 2016.

Purwanto, M. Ngalim. Ilmu Pendidikan Teoritis dan Praktis, (Bandung: Remaja Rosdakarya, 1994.
Rahayu, Sri. Belajar Mudah SPSS Versi 11.05. Bandung: Alfabeta, 2004.

Safaruddin. Heriditas dan Lingkungan Pendidikan Islam. Al-Qalam, Vol.6, No.1. 2014.

Salahuddin, Anas. Filsafat Pendidikan. Bandung: Pustaka Setia, 2011.

Sani Supriyanto, Ahmad. Dkk. Metodelogi Penelitian Manajemen Sumber Daya Manusia Teori, Kuisioner, dan Analisis Data. Malang: UIN-Maliki Press, 2013.

Santoso, Singgih. Buku Latihan SPSS Statistik Parametrik. Jakarta: PT. Eka Media Komputerindo, 2001.

Scarborough, Norman M., and Zimmerer, Thomas W. Effective Small Business Management, $4^{\text {th }}$ ed. New York: MacMillan Publ. Company, 1993.

Segal, Borgia and Schoenfeld, Jerry. The Motivation To Become An Entrepreneur International Journal of Entrepreneurial Behaviour \& Research, Vol.11 No.1 2005.

Slameto. Belajar dan Faktor-faktor yang Mempengaruhinya. Jakarta: Rineka Cipta, 2010.

Soelaeman. Pendidikan dalam Keluarga. Bandung: IKAPI, 1994.

Suryana, Yuyus dan Bayu, Kartib. Kewirausahaan: Pendekatan Karakteristik Wirausahawan Sukses.Jakarta: Kencana, 2011.

Suryana. KEWIRAUSAHAAN: Pedoman Praktis: Kiat dan Proses Menuju Sukses. Jakarta: Salemba Empat, 2006.

Suhardi, Theo. ENTREPRENEURSHIP: Menumbuhkembangkan Usaha Mikro dan Kecil. Bandung: UNPAD Press, 2009.

Supardi, Ajah. Motivasi Wirausaha dan Faktor Lingkungan terhadap Minat Wirausaha. Tesis. UNPAD Bandung: 
Program Magister Manajemen, Fakultas Ekonomi dan Bisnis, 2016.

Sujanto, Agus. Psikologi Sosial. Jakarta: Rineka Cipta, 2004.

Suryaman, Maman. Minat Wirausaha pada Mahasiswa Pendidikan Teknik Elektro Fakultas Teknik Universitas Negeri Semarang. Skripsi. Universitas Negeri Semarang, 2006.

Sugiono. Metode Penelitian Kuantitatif, Kualitatif, dan $R \& D$, (Bandung: ALFABETA, 2012.

Supriyanto, Ahmad Sani. Dkk. Metodelogi Penelitian Manajemen Sumber Daya Manusia Teori, Kuesioner, dan Analisis Data. Malang: UIN-Maliki Press, 2013.

Tafsir, Ahmad. Ilmu Pendidikan dalam Perspektif Islam. Bandung: Remaja Rosdakarya, 1991.

Taormina, Robert J. and Kin-Mei Lao, Sammi. Measuring Chinese Entrepreneurial Motivation (Personality and Environmental Influences). International Journal of Entrepreneurial Behavior \& Research Vol.13 No.4, 2007 pp.200-221.

Tim Litbang Wahana Komputer. Ragam Model Penelitian \& Pengolahannya dengan SPSS. Yogyakarta: ANDI, 2017.

Tim Penyusun Kamus. Pusat Pembinaan dan Pengembangan Bahasa. Jakarta: Balai Pustaka,1998.

Widayatun, Tri Rusmi. Ilmu Prilaku. Jakarta: CV. Sagung Seto, 2009.

Winkel. Psikologi Pengajaran. Yogyakarta: Media Abadi, 2004.

Wiryasaputra, Totok S. Entrepreneur: Anda Merdeka jadi Bos. Jakarta: Tridharma Manunggal, 2004.

Yusuf. L.N., Syamsu. Psikologi Perkembangan Anak dan Remaja. Bandung: Remaja Rosdakarya, 2009.
Ziemik, Manfred. Pesantren dalam Perubahan Sosial. Jakarta: P3M, 1986.

Badan Pusat Statistik (BPS) Republik Indonesia, 2015.

Ketua Umum Badan Pengrus Pusat Himpunan Pengusaha Muda (BPP HIPMI), Bahlil,Lahadalia.http://www.suara.co m/bisnis/2016/05/09/133306/jumlahpengusaha-di-indonesia-baru-15persen-dari-total-penduduk. (diakses 19 November 2016).

Program/Kegiatan Strategis Kementrian Koperasi dan UKM Tahun 2015, Deputi Bidang Pengembangan SDM.

Sosialisasi Kurikulum Tingkat Satuan Pendidikan (KTSP), http://file.upi.edu/Direk...Compatibilit y_Mode\%5d.pdf. (diakses 26 November 2016).

Undang-Undang Dasar Republik Indonesia No.20 Tahun 2003 tentang Sistem Pendidikan Nasional. 